Anna Tüskés

\title{
Masonic Works in the Helikon Library of the Festetics Palace in Keszthely
}

Books were very important for the Festetics family settled down in Keszthely in the second half of the 1740s: the bookstore had been created in Kristóf Festetics's palace. ${ }^{1}$ From 1782 Count György Festetics (I.) had been the lord of the entail, he was one of the most outstanding personalities of the Hungarian Enlightenment and had a whole annexe built to his library between 1799-1801. ${ }^{2}$ The library room can be found with a small adjoining cabinet library in the south wing of the palace. In the many ten thousand-volume library can equally be found works of antique authors, Hungarian literature and science, philosophical literature from the era of Enlightenment, the latest economic studies at the time of acquisition, as well as a significant newspaper and journal material. The library of Keszthely is a baronial library so the collection of books and the motivation of reading were combined when the books were purchased. ${ }^{3}$

György Festetics studied at the Collegium Theresianum in Vienna between 1768-1775. ${ }^{4}$ He had well-trained Jesuit teachers, such as the professor of philosophy, Italian language and agronomics, Lajos Mitterpacher, the mathematician and physicist Pál Makó, the professor of Italian language, civil and military architecture, János Izzo, the poet, bibliographer, insect expert Michael Denis and many others. ${ }^{5}$ During his studies, Festetics perfectly learned German, Latin, French, Italian and English. Besides Austrian state administration

1 Károly Klempa: A keszthelyi Festetics könyvtár [The Festetics Library in Keszthely]. Keszthely 1938, p. 24; Antal Csendes: Helikon Library, Keszthely. Budapest 1989; Éva Hargitainé Vári: A Festetics kastély Helikon könyvtára [The Helikon Library of the Festetics Palace]. In: Keszthelyi Festetics Kastély. Ed. by Zsolt Virág. Keszthely 2015, pp. 125-131.

2 Rebecca A. Gates: Aristocratic Libraries, Censorship, and Bookprinting in Late-EighteenthCentury Hungary. In: The Journal of Library History 22 (1987), 1, pp. 23-41, here p. 35.

3 Attila Buda, Anna Tüskés: Horatius, Ovidius és Vergilius müvei főúri könyvgyüjteményekben. A fóti Károlyi-kastély egykori és a keszthelyi Festetics-kastély Helikon könyvtára [Works of Horace, Ovid and Virgil in the former library of the Károlyi Castle in Fót and in the Helikon Library of the Festetics Castle in Keszthely.] In: Római költők a 18-19. századi magyarországi irodalomban: Vergilius, Horatius, Ovidius. Ed. by Piroska Balogh, Réka Lengyel. Budapest 2017, pp. 324-355.

4 György Kurucz: Keszthely grófja: Festetics György [Count of Keszthely: György Festetics]. Budapest 2013, pp. 77-80.

5 Johann Schwarz: Geschichte der k. k. Theresianischen Akademie von ihrer Gründung bis zum Curatorium Sr. Exzellenz Anton Ritter von Schmerling 1746-1865. In: Jahres-Bericht 
studies, through philosophical and legal studies he also gained Hungarian public and state law knowledge. During his studies in Vienna, he became acquainted with the literature of French Enlightenment and Freemasonry. ${ }^{6}$ At the Theresianum in Vienna he met his later brother-in-law, Count Ferenc Széchényi with whom friendship did not break even after school, but lived mostly through correspondence. $^{7}$

During his chamber official and military career he travelled a lot even beyond the borders of the Habsburg Empire. From 1786 he served as a Major in the Hungarian noble bodyguard, so he could have been closer to his family and to his estates. Although he stayed for a short time in Vienna, he could meet many people and actively participate in sessions and meetings of Freemasons. He joined the regenerative philosophical, deist movement of rationalist Freemasonry, he became member of the Lodge of True Concord (St. Johannis-Freimaurerloge "Zur wahren Eintracht") founded in 1781 with fifteen members. ${ }^{8}$ The lodge had also Hungarian visitors and members ${ }^{9}$ : for example the bodyguard Károly Gyárfás, the physician of Cluj-Napoca Mihály Kassay, the Chamberlain, lord-lieutenant Count Lajos Batthyány (II.), Lieutenant, the General Count József Miklós Pálffy, the Chamberlain, lord-lieutenant Count György Antal Apponyi, the cadet János Domokos, the Secretary Counsellor, Chief lieutenant Count Lipót Pállfy, József Pákei, teacher of the Unitarian college in Cluj, the educator János Széplaki, the phsycian András Szőts, the Court secretary, scholar János Dániel Ribini, and the writer, poet Ferenc Kazinczy. György Festetics’s number in the lodge 488 can be found on the title page of the volumes of Journal für Freymaurer published by the lodge in $1786 .^{10}$

There are about twenty-five periodicals and books closely related to Freemasonry, Rosicrucians, Illuminati, Templars and the Order of Maltese from the eighteenth century, mostly in German, Hungarian and French in the today library of Festetics Palace in Keszthely. Several books contain the exlibris

über das Gymnasium der k. k. Theresianischen Akademie in Wien für das Schuljahr 1890 (1890) pp. 3-110.

6 Kurucz (note 4.), pp. 81-95.

7 George Barany: Hoping Against Hope. The Enlightened Age in Hungary. In: The American Historical Review 76 (1971), 2, pp. 319-357, here p. 351.

8 Géza Cséby: Gróf Festetics György helye a magyar müvelődéstörténetben, különös tekintettel a Magyar Minerva könyvsorozatra és a Helikoni ünnepségekre [Count György Festetics in the Hungarian Cultural History, with special regard to the Hungarian Minerva Book Series and the Helikon Festivities]. PhD dissertation. Szeged 2013.

9 Ludwig Abafi: Geschichte der Freimaurerei in Österreich-Ungarn. Budapest, 1890-1899, vol. IV, pp. 278-318.

10 Helikon Library, Keszthely: Inv. no. Periodica 24/8. 
depicting the coat of arms of the Festetics family, and in some books György Festetics's autograph entries can be read in Ancient Greek and French. ${ }^{11}$ What do these entries say? Are there any evidences of the acquisition of these books in the twelve eighteenth-century catalogues which have survived in the family archives, or on the acquisition lists and journal subscriptions? What is the subject of these books? I try to find answers to these questions in my lecture.

The archives of the Festetics family kept in the Hungarian National Archives the material of box 246 entitled "The Files of the Library of Keszthely", contains a number of library catalogues, records, receipts, lists copied from auction catalogues, list of books planned to be purchased from Vienna and Pest, subscription of periodicals and manuscript catalogues. ${ }^{12}$ I managed to identify twelve library catalogues: seven have the date of composition, the other five have no year mark, but I concluded the date of the creation from the date of the latest publishing time which could be find in them. These twelve catalogues were created over a period of one and a half centuries - between 1746 and 1894 - containing the library inventory of several Festetics libraries: beside the library of Keszthely, inventories of the book collection of the Mansion of Baltavar and the Mansion of Ság of the Festetics estate can also be found. It is worth mentioning that the Mansion of Baltavár (today Bérbaltavár) was destroyed in the early 20th century, and that György Festetics, the prosperer of the library of Keszthely was born in the Mansion of Ság (today Simaság) in 1755. Among these twelve catalogues, the catalogue of the library of Keszthely created around 1793 is the most interesting in our point of views. This contains the book collection at that time, in the alphabetical order of the initial of the author's name, or if it is missing, the initial of the title of the book. It contains numerous works of belles-lettres and political literature of the era of the Enlightenment as well as books and periodicals closely related to Freemasory, Illuminati and Rosicrucians, mainly in the "Secr." section (Fig. 1.). Here is the list of the books numbered from 1 to 24 with the actual inventory number of the book if it exists in the current collection:

Secr. 1. Lieder verfasst von den Brüdern der Loge zur Wahren Eintracht. [S. 1. e. a.] Secr. 2. Christian Ernst Wünsch: Horus oder Astrognostisches Endurtheil über die Offenbarung Johannis und über die Weissagungen auf den Messias wie auch über Jesum und seine Jünger. Mit einem Anhange von Europens neuern Aufklärung und von der Bestimmung des Menschen durch Gott. Eine Lesebuch zur

11 I am grateful to Éva H. Vári for helping in the research.

12 Hungarian National Archives, Budapest: P274 XI.2. 


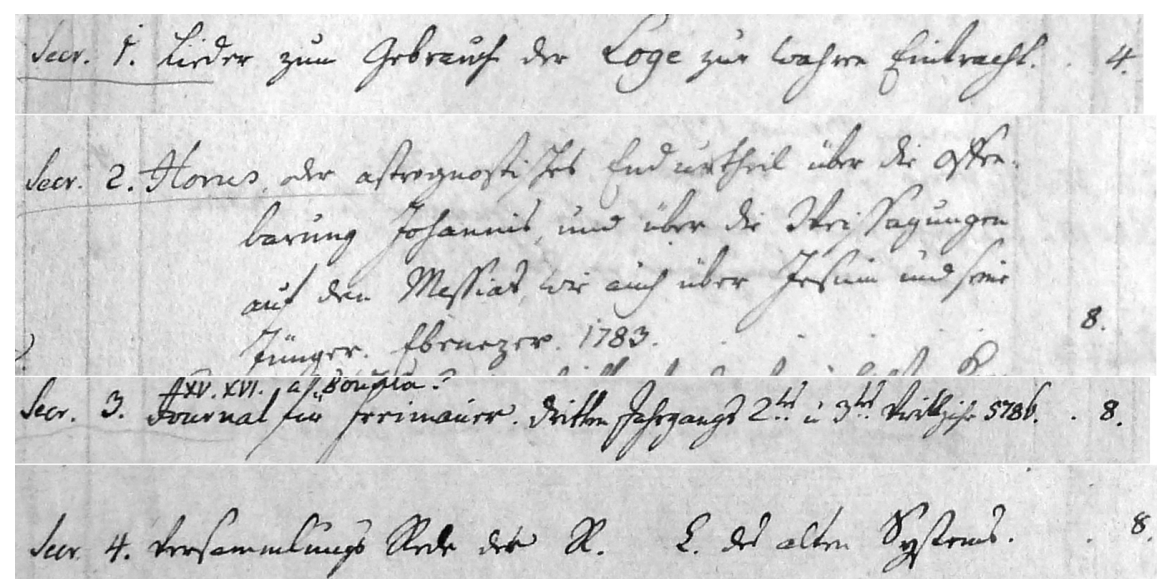

Fig. 1: Books numbered from 1 to 4 in the "Secr." Section in the catalogue of the library of Keszthely created around 1793. Hungarian National Archives, Budapest.

Erholung für die Gelehrten und ein Denkzettel für Freimaurer. Ebenezer 1783. Inv. no. Theol. 258.

Secr. 3. Journal für Freymaurer. Bd. 2. and 3. Wien 1786. Inv. no. Periodica 24/ 8.

Secr. 4. Versammlungs-Rede der R. C. des alten Systems. [S. 1.] [1779]. Inv. no. Eph. 416.

Secr. 5. [Felix Hofstäter:] Wahrmund, oder Antwort auf alte Verleumdungen wider Jesuiten, wie sie in den neuesten Schmähschriften wiederholt sind. In Unterredungen, worinn die Einwürfe wider Wurzens fürtrefliche Rede entblösst, und die Stümmeleyen Verdrehungen, Fälschungen in der Geschichte sowohl, als in der Sittenlehre aufgedeckt werden. Bd. 1. Augsburg 1782. Inv. no. Theol. 547.

Secr. 6. Johann Gottlieb Naumann: Vierzig Freymäurerlieder. In Musik gesetzt. Berlin 1782. Inv. no. Lit. Ger. 72.

Secr. 7. Thomas Newton: Abhandlungen über die Weissagungen, die merkwürdig erfüllet sind, und noch bis auf den heutigen Tag in ihre Erfüllung gehen. Aus dem Englischen übers. Frankfurt, Leipzig 1782. Inv. no. Theol. 546.

Secr. 8. Aloys Blumauer: Gedichte und Lieder verfasst von den Brüdern der Loge zur Wahren Eintracht in O. v. W+++. Wien 1783. Inv. no. Lit.Ger. 192.

Secr. 9. Ueber geheime Wissenschaften, Initationen und neuere Verbindungen. Bd. 1-2. Altenburg 1786-1787. Inv. no. Hist. Univ. 1612.

Secr. 10. Friedrich Wadzeck: Leben und Schicksale des berüchtigten Franz Rudolph von Grossing, eigentlich Franz Matthäus Grossinger genannt, nebst der 
Geschichte und Bekanntmachung der Geheimnisse des Rosen-Ordens. Frankfurt, Leipzig 1789. Inv. no. Hist. Univ. 660.

Secr. 11. Adam Weishaupt: Vollständige Geschichte der Verfolgung der Illuminaten in Bayern. Bd. 1. Frankfurt, Leipzig 1786. Inv. no. Hist. Univ. 761.

Secr. 13. Adam Weishaupt: Nachtrag von weitern Originalschriften, welche die Illuminatensekte überhaupt, sonderbar aber den Stifter derselben Adam Weishaupt. München 1787. Inv. no. Hist. Univ. 3638.

Secr. 15. Adam Weishaupt: Apologie der Illuminaten. Frankfurth, Leipzig 1786. Inv. no. Hist. Univ. 784.

Secr. 16. Hans Carl Ecker und Eckhoffen: Der Rosenkreuzer in seiner Blösse. Zum Nutzen der Staaten hingestellt durch Zweifel wider die wahre Weisheit der so genannten ächten Freymaurer oder goldnen Rosenkreutzer des alten Systems von Magister Pianco. Amsterdam 1781. Inv. no. Hist. Univ. 1725.

Secr. 17. Ernst August Anton von Göchhausen: Vollendeter Aufschluss des Jesuitismus und des wahren Geheimnisses der Freimaurer. Rom [Züllichau] 1787.

Secr. 18. Franz Xaver Zwack(h): Einige Originalschriften des Illuminatenordens. Welche bey dem gewesenen Regierungsrath Zwack durch vorgenommene Hausvisitation zu Landshut den 11. und 12. Oktob. [et]c. 1786. vorgefunden worden. München 1787. Inv. no. Hist. Univ. 766.

Secr. 19. Johann Christian Edelmann: Moses mit Aufgedeckten Angesichte von zwey ungleichen Brüdern, Lichtlieb und Blindling beschauet nach Art der unschuldigen Wahrheiten in einem freymüthigen Gespräche abgehandelt, und Licht- und Klarheit-liebenden Gemüthern zu Gott geheiligter Bewundrung und Ergötzung vorgestellt. Freyburg 1740. Inv. no. Theol. 514.

Secr. 20. Ernst August Anton Göchhausen: Aufschluss und Vertheidigung der Enthüllung des Systems der Weltbürger-Republik. Rom [Züllichau] 1787. Inv. no. Hist. Univ. 3013.

Secr. 21. Leopold Alois Hoffmann: Achtzehn Paragraphen über Katholizismus, Protestantismus, Jesuitismus, geheime Orden und moderne Aufklärung in Deutschland. Wien 1787. Inv. no. Juris. 1062.

Secr. 22. Adam Weishaupt: Das verbesserte System der Illuminaten mit allen seinen Einrichtungen und Graden. Frankfurth, Leipzig 1787. Inv. no. Hist. Univ. 1408.

Secr. 23. System und Folgen des Illuminatenordens aus den gedrucktten Originalschriften desselben gezogen. In Briefen. München 1787. Inv. no. Hist. Univ. 2035.

Secr. 24. Théodore Henri Tschudy: Der flammende stern Oder die Gesellschaft der Freymäurer von allen Seiten betrachtet. Aus dem Französischen. [S. 1.] 1779. Inv. no. Hist. Univ. 1763. 
Two numbers are missing from the library catalogue, the number 12 and 14 . From the remaining 22 books I could not identify one item, the number 1, and there is still one work missing from the current book collection, the number 17 , so 20 works can be studied today in the library of the Palace. The numbering of books from 1 to 24 does not show the chronological order of the publication, but is likely to reflect a purchase order. Considering the spatial distribution of the printing place of the books, it can be concluded that works published in Vienna, Frankfurt-Leipzig and works with false location mark - like Rome instead of Züllichau (today Sulechów, Poland) - are the most common.

In terms of their language and size, most works are octavo and written in German. The ex-libris depicting the Festetics coat of arms can be seen labelled in some of the books on the inner side of the first book cover, for example in the book of the French writer, journalist, theatre director Jean Pierre Louis de La Roche du Maine titled Essai sur la secte des Illuminés published in London in 1789 in which he condemned the leaders of the Bavarian Illuminati and accused them of directing Freemasonry generally in Europe especially in France. ${ }^{13}$ Ex-libris can also be seen in the book on the system of the Cosmopolitan Republic by the German writer, Freemason, Court Counsellor in Weimar, Ernst August Anton Göchhausen published in $1789 .^{14}$

The research has so far dealt mainly with one freemason print from the library collection of Keszthely: the eight-leaf booklet titled Versammlungs-Rede der in $1786 R C$ des alten Systems preserved in the third volume of Journal für Freymaurer of 1786, under the 3rd number in the library catalogue, published by the Lodge of True Concord led by Ignaz von Born. In the catalogue, the booklet is a separate item with serial number 4 so it was not originally related to the journal. On the front page, one can read "Gehalten vom $\mathrm{Br}$ [uder] Heliconus. Am 21. 9. 79." that is, the speech was given by Brother Helicon on the 21st September 1779 (Fig. 2.). An ink drawing can also be seen: a serpent waving around the globe with a cross standing on the crescent. Three researchers - Dezső Keresztury, István Tóth and György Kurucz - interpreted this recording that Helicon was the name of György Festetics in the Lodge of True Concord and this form was his masonic introductory speech, and this is where the appellation of literary Helikon festival launched by the Count of Keszthely in 1817 derives

13 Jacques Droz: La légende du complot illuministe et les origines du romantisme politique en Allemagne. In: Revue Historique 226 (1961), Fasc. 2, pp. 313-338; J. M. Roberts: The Mythology of the Secret Societies. London 1972.

14 Reinhard Lauth: Nouvelles recherches sur Reinhold et l'Aufklaerung. In: Archives de Philosophie 42 (1979), 4, pp. 593-629, here pp. 627-629. 


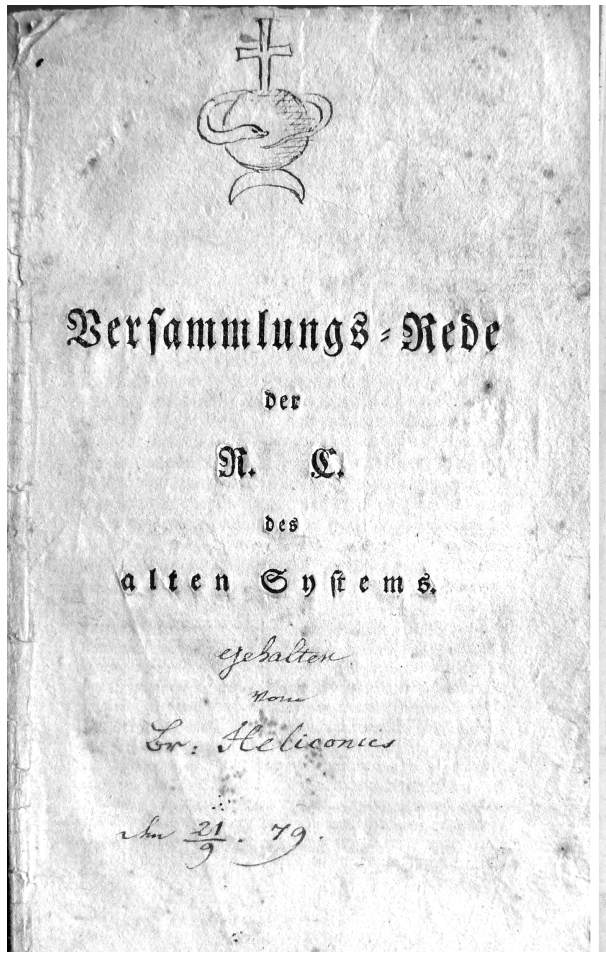

\section{Berfammlung: = Ole De}

ser

Si. $\mathfrak{C}$.

DeB

a It

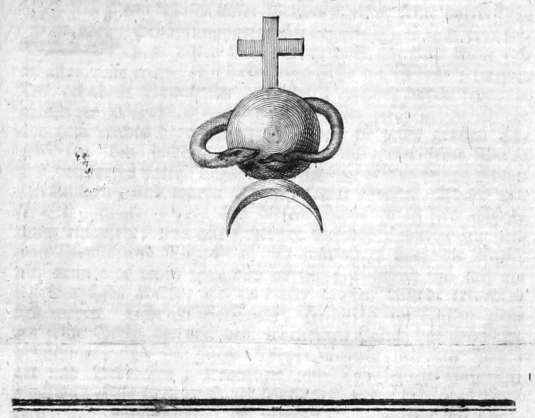

DI 佂 ET,

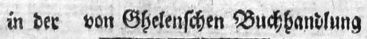

Fig. 2: Versammlungs-Rede der in 1786 RC des alten Systems. First and second edition (1779: Helikon Library, Keszthely, 1781: Moravian Library, Brno).

from. ${ }^{15}$ Gergely Forizs pointed out in 2014 that the author of the speech is not Festetics. ${ }^{16}$ He discovered that the date of the speech on the title-page, 21st of September in 1779 was the date of the foundation of the Heliconus Gold and Rosicrucian circle in Berlin, and Heliconus himself can be identified with Johann Christoph Wöllner, the great master of the circle. ${ }^{17}$ As far as the question of how Festetics obtained the Rosicrucian booklet under the stickiest secrecy,

15 Dezső Keresztury: Híres magyar könyvtárak [Famous Hungarian Libraries]. Budapest 1982, pp. 70-71; István Tóth: A keszthelyi Helikon nevének eredete [The origin of Helikon's name in Keszthely]. In: Múzeumi Kurír 4 (1980), pp. 7-8; Kurucz 4.), p. 96.

16 Gergely Fórizs: Kurucz György, Keszthely grófja Festetics György. Budapest, Corvina, 2013. (Review) http://reciti.hu/2014/2387, 21st December 2014.

17 C. Lenning: Encyclopädie der Freimaurerei. Leipzig 1867. Bd. III. p. 247. Guy Stanton Ford: Wöllner and the Prussian Religious Edict of 1788, I. In: The American Historical Review 15 (1910), 2, pp. 264-280. 
printed in collaboration by Georg Jakob Decker one of the printer members of the Order, so far it has not been possible to find any answer. Anyway, it can be assumed that Festetics had a masonic relationship network even beyond the borders of the monarchy. This publication also has a second edition in 1781 in Vienna at of Ghelen Publishers on which we can see the motif of the serpent waving around the globe with a cross standing on the crescent in woodcut. ${ }^{18}$

Besides the Journal für Freymaurer, two more items are closely related to the Viennese Lodge of True Concord both of them contain songs composed in the lodge: Secr. 1. and Secr. 8. The author of the latter is the Austrian poet Aloys Blumauer who had been the member of the lodge since $1781 .^{19}$ Other items also prove that music was important to Festetics: Secr.6. contains Forty freemason songs for Freemason rituals by the German composer and conductor Johann Gottlieb Naumann. ${ }^{20}$ In the autumn of 1799 Festetics invited the clarinet virtuoso Anton Stadler, a close friend of Mozart, to develop a plan for the foundation of a music school. ${ }^{21}$

If we take a closer look at the authors, we can see Adam Weishaupt's four works and Ernst Göchhausen's two works. From other authors there are oneone work in the catalogue. Weishaupt is the founder of the Illuminati Order, Freemason, university professor and philosopher. ${ }^{22}$ As strongly opposed to Jesuits, he became increasingly liberal in his religious and political views, supporting deism and republicanism. The Order which was established in 1776 and was banned in 1784 had been designed to develop morality and virtue and to establish an alliance of good people to counteract the progress of the evil.

18 Copies: Moravian Library in Brno, inv. no. Fr-0253.853; Geheimes Staatsarchiv Preußischer Kulturbesitz, FM, 5.2 D 34 Nr. 1761. Renko Geffarth: Religion und arkane Hierarchie. Der Orden der Gold- und Rosenkreuzer als Geheime Kirche im 18. Jahrhundert. Leiden, Boston 2007, p. 202.

19 Bärbel Becker-Cantarino: Aloys Blumauer and the Literature of Austrian Enlightenment. Bern, Frankfurt/M. 1973.

20 Paul Nettl, Theodore Baker: Freemasons' Music in the Eighteenth Century. In: The Musical Quarterly 16 (1930), 2, pp. 191-198, here p. 196; Cecil Hill: Masonic music. In: The New Grove Dictionary of Music and Musicians. Ed. Stanley Sadie. Oxford 1980. Vol. 11, pp. 753-756.

21 Pamela L. Poulin: A View of Eighteenth-Century Musical Life and Training: Anton Stadler's “Musick Plan” In: Music \& Letters 71 (1990), 2, pp. 215-224.

22 Monika Neugebauer-Wölk: Debatten im Geheimraum der Aufklärung. Konstellationen des Wissensgewinns im Orden der Illuminaten. In: Geschichte und Gesellschaft. Sonderheft, Die Aufklärung und ihre Weltwirkung 23 (2010), pp. 17-46; Reinhard Markner: Woellner, Johann Christoph (1732-1800). In: Le Monde maçonnique au XVIIIe siècle. Éd. par Charles Porset, Cécile Révauger. Paris 2013. Vol. 3, pp. 2820-2824. 
Festetics got two woks from German writer, Duke Councillor, freemason Ernst Göchhausen: one work on Jesuitism and Freemasonry, the other on the system of the Cosmopolitan Republic. ${ }^{23}$ There are works from nine other authors in the Secret section in the book catalogue of 1793: 1. The book on Rosicrucians of the German lawyer, freemason writer, Hans Carl Freiherr von Ecker und Eckhoffen, which he wrote after his exclusion from the "Gold- und Rosenkreuzer" Order. ${ }^{24}$ 2. The book titled Moses... by the German pietist Johann Christian Edelmann, writer of the Early Enlightenment, in which he denies the biblical faith and Christian dogma. All available copies of this book had been burned by the Imperial Book Commission in 1750 in Berlin. ${ }^{25}$ In the last period of his life, Edelmann had a close relationship with Freemasons in Hamburg and Berlin, and he was member of the "Freemasonry Society of Hamburg". 3. The booklet entitled Eighteen paragraphs on Catholicism, Protestantism, Jesuitism, Secret Commands, and Modern Enlightenment in Germany of writer Leopold Alois Hoffmann, the secretary of the lodge "Zur Wohltätigkeit" ["For Good Actions"] in Vienna. 4. The first volume of the work on Jesuits by the writer and librarian Felix Franz Hofstäter's who published the journal "Magazin für Kunst und Literatur” between 1793-1796. 5. The English bishop, writer, biblical scholar Thomas Newton's book on prophecies in German translation. 6. French lawyer pamphletist Théodore Henri Tschudy's work on Freemasons in German translation. 7. The book by Friedrich Wadzeck, member of the Freemason lodge "Zum flammenden Stern" ("To the Flaming Star") in Berlin, on the life and destiny of the notorious Franz Rudolph von Grossing as well as on the story of the Secretaries of the Order of Roses written in the form of question-answer. 8. The German mathematician, physicist Christian Ernst Wünsch's work entitled Horus. .. published in 1783, presenting an astral-mythological system, which was intended as a reading book for scholars and freemasons. ${ }^{26}$ Anyway, from 1784 he was a teacher at Brandenburg University in Frankfurt and became a member of the Freemason lodge "Zum aufrichtigen Herzen" ["To the sincere heart"]. 9. The book representing illuminati documents found in the house of

23 Rüdiger Hachtmann: Friedrich II. von Preußen und die Freimaurerei. In: Historische Zeitschrift 264 (1997), 1, pp. 21-54.

24 Andreas B. Kilcher: Franz Joseph Molitors Kabbala-Projekt vor dem Hintergrund seiner intellektuellen Biographie. In: Zeitschrift für Religions- und Geistesgeschichte 55 (2003), 2, pp. 138-166.

25 Walter Grossmann: Johann Christian Edelmann's Idea of Jesus. In: The Harvard Theological Review 60 (1967), 4, pp. 375-389, here p. 389.

26 Jürgen von Kempski: Apokalypse, “Horus” und Wünsch. In: Zeitschrift für Religions- und Geistesgeschichte 47 (1995), 4, pp. 304-319. 
the philosopher, Freemason, royal Bavarian State Councilman, Franz Xaver Zwack in $1786 .^{27}$ Zwack was prosecuted in 1785 when the Order of Illuminati was banned in Bavaria of which he was one of the founders.

By reviewing the works listed in Secr. section, it can be stated that the catalogue of 1793 of György Festetics's library contains a number of foreign works related to Freemasonry or subjects and they are still in the book collection of the library of Palace of Keszthely. According to the books, Festetics's foreign masonic interest was directed towards three main centres: the Lodge of True Concord in Vienna, the Bavarian Illuminati and the North German (Berlin and Leipzig) Freemasons.

In the Secret Section of the catalogue of 1793, exclusively foreign authors' foreign-language works related to Freemasonry can be found. Works of Hungarian authors and works of foreign authors in Hungarian translation are in Patr. section. Some examples: the French Fenouillot de Falbaire de Quingey's fiveact rhymed drama L'Honnête Criminel, ou l'Amour filial (1767) in Hungarian translation by György Aranka; the poems of the Swiss poet and painter Salomon Gessner translated by Ferenc Kazinczy Geszner Idylliumi, Kassa, 1788; two works by Ádám Pálóczi Horváth: Nyári Ejtzaka (Summer night) and Psychologia azaz a Lélekről való Tudomány (Psychology i.e. Science of the Spirit).

There are such eighteenth-century works related to masonic works in the current book collection of the library of Keszthely which are not included in the catalogue of 1793 due to their subsequent publication and/or acquisition. Two works deal with the Templars and one with the Knights of Malta. ${ }^{28}$ It is important to mention: 1. An other work of the above mentioned Hans Carl Freiherr von Ecker und Eckhoffen, the Für Lessing wider Gertinger und Seine Anhänger published in 1781; 2. The book of Boldizsár Pongrácz, the Magistrate of several counties and founding grandmaster ${ }^{29}$ The most necessary and profitable craftsmanship in worldly life" (Az embernek e' világi életben leg-szükségessebb és

27 Monika Neugebauer-Wölk: Debatten im Geheimraum der Aufklärung. Konstellationen des Wissensgewinns im Orden der Illuminaten. In: Geschichte und Gesellschaft. Sonderheft, Vol. 23, Die Aufklärung und ihre Weltwirkung (2010), pp. 17-46.

28 Wilhelm Christian Stemler: Contingent zur Geschichte der Templer und der Aufhebung ihres Ordens von -. Leipzig 1783. Inv. no. Hist. Univ. 1555.; Friedrich Münter: Statutenbuch des Ordens der Tempelherren. Aus einer altfranzösischen Handschrift hrsg. Und erlautert von -. 1 . Theil. Berlin 1794. Inv. no. Hist. Univ. 1303.; I. N. Langenfeld: Kurzgefasste pragmatische Geschichte des Malteserordens von dessen Ursprunge, Schicksalen, Thaten und Obliegenheiten sammt dem Verzeichnisse alter dessen Grossmeister. Gewidmet von -. München 1783. Inv. no. Hist. Univ. 1539.

29 János Belitzky: Nógrád megye története I. 896-1849 [History of Nógrád County I. 8961849]. Salgótarján 1972, p. 385, n. 33. 
leghasznossabb mesterség) published in Pest in 1783; 3. The also mentioned Ádám Pálóczi Horváth A Secret Revealed: That is the Confession of a Young Man who has long been trying to become Freemason (Fel-fedezett titok Az-az Vallástétele egy ollyan Túdós Ifjúnak, a' ki sokáig igyekezett rajta, hogy Frajmaurer lehessen) published in $1792^{30}$; 4. and the three volumes of journal the Urania published in 1794-1795 which was supported also by Festetics.

Finally, I present three books, each with autograph entry of György Festetics. 1. The first is the book of Georg Schmid: the Allgemeine Grundregeln der Freymaurer published in 1785 in Bratislava (Fig. 3.). ${ }^{31}$ According to the book entry he purchased it in Leipzig. The work includes a short thesis on the basic masonic rules of thinking, behaviour and work, as well as Joseph Stettner's speech on the purposes of Freemasonry.

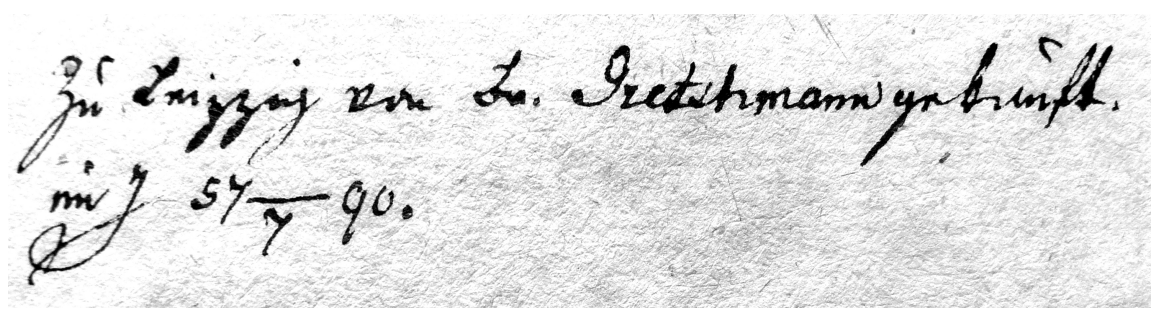

Fig. 3: Autograph entry of György Festetics in the copy of the book by Georg Schmid, Allgemeine Grundregeln der Freymaurer. Helikon Library, Keszthely.

2. Besides the Festetics ex libris, György Festetics's autograph entry in Ancient Greek can be read on the front page of the edition of 1761 of the book by the English traveller jr. Edward Wortley Montagu on the history of Ancient States (Betrachtungen über die Aufnahme und den Verfall der Alten Republiken oder freyen Staaten, mit einer Anwendung auf den gegenwärtigen Zustand von Grossbritannien) ${ }^{32}$ : this is a quotation from the Works and Days of Hesiodos (Fig. 4.).

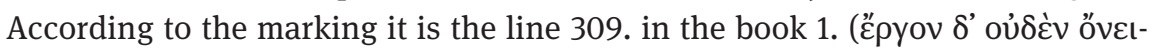

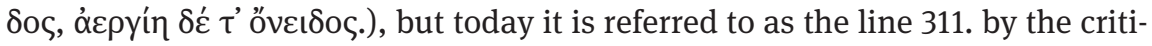
cal editions. In English translation: "Work is no disgrace. It is an idleness

30 For a partial English translation see Ádám Pálóczi Horváth: A secret revealed (1781). Translated by Bernard Adams. In: Learned Societies, Freemasonry, Sciences and Literature in 18thcentury Hungary: A Collection of Documents and Sources. Ed. by Réka Lengyel, Gábor Tüskés, Budapest, MTA BTK Irodalomtudományi Intézet, 2017, 204-216.

31 Inv. No. Hist. Univ. 1056.

32 Inv. No. Hist. Univ. 1385. 

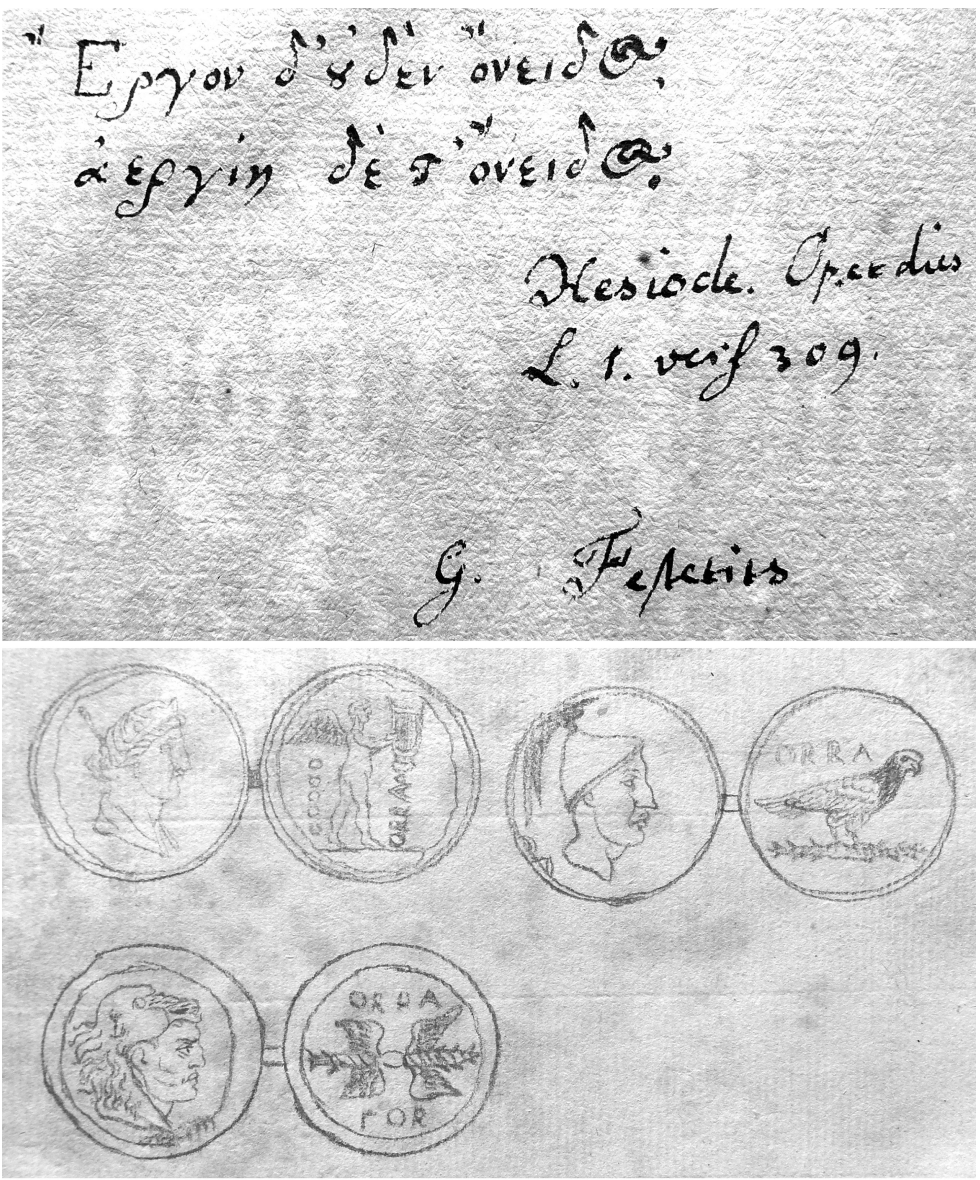

Qeteins pafse ma livonye.
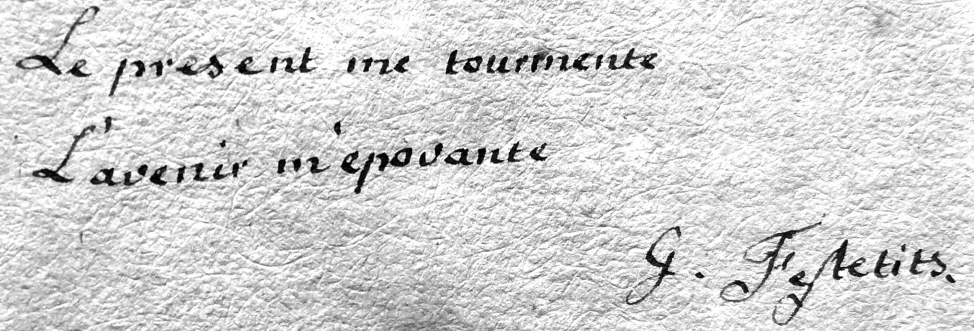

Fig. 4: Autograph entry of György Festetics in the copy of the book by jr. Edward Wortley Montagu, Betrachtungen über die Aufnahme und den Verfall der Alten Republiken. Helikon Library, Keszthely. 
which is a disgrace." The work firstly appeared two years earlier in English, and analyses the impact of the eighteenth-century crises in the context of the Ancient States - the Seven Years War and the American War of Independence - on Britain. The book contains a sheet with the drawings of the front and back side of three antique Greek medals. They has the same epigraph: ORRA which means that they are the coins of the city of Orra (today Oria) in Calabria, used in the second and first century B. C. ${ }^{33}$

At the end of the book, on the opposite side of the table of contents, an entry from György Festetics can be read in French: "Le tem[p]s passé m'a trompé, / Le present me tourmente / L'avenir m'epouvante / G. Festetits”. This means: "The past deceived me. The present torments me. The future terrifies me." This proverb was widespread at the end of the eighteenth century, for example, an eight-page booklet on Napoleon was published with this title in 1799 signed by J.-M. Bouverot.

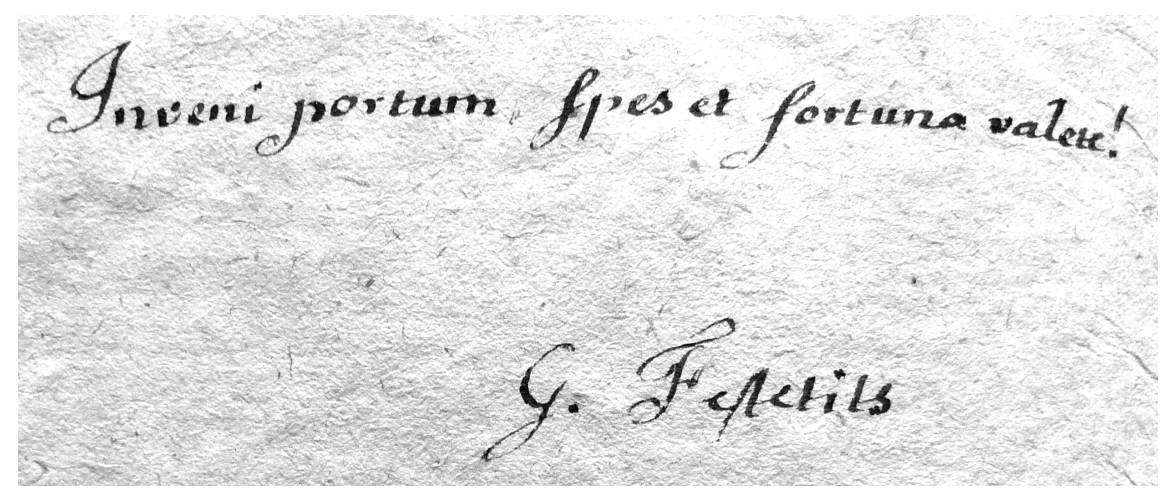

Fig. 5: Autograph entry of György Festetics in the copy of the book by Pál Makó, Compendiaria metaphysicae institution. Helikon Library, Keszthely.

3. The same French quotation can be read also in other books of the library, for example at the end of the copy of the third edition of Compendiaria metaphysicae institutio (Vindobonae, 1769) by Pál Makó, the teacher of Festetics in the

33 H. Dressel: Berlin, Königliche Museen. Beschreibung der antiken Münzen. Berlin 18881894. Bd. III. Abtheilung 1. Italien: aes rude, aes signatum, aes grave. Die geprägten Münzen von Etrurien bis Calabrien. Berlin 1894, p. 221. 
Collegium Theresianum, the representative of a special version of the Catholics Enlightenment in Vienna. ${ }^{34}$ There is an autograph Latin quotation by Festetics on the page facing the title-page of this book: "Inveni portum, spes et fortuna valete!" (Fig. 5.). The meaning of the first line of the Ancient Greek epigram ${ }^{35}$ by unknown author means "Finally I found my port. I tell you goodbye Hope and Luck." After the fifteenth-sixteenth-century humanist poets, this ancient distich has been rediscovered in the eighteenth century. According to the book entry, this epigram thought could have been important to Festetics as well.

34 Inv. No. Philos. 98.

35 Anthologia Palatina, IX. 49. Friedrich Jacobs, Anton Jacob Paulssen, Charles Anthon: Anthologia Graeca. Lipsia 1813-1817, vol. II, p. 20. 